\title{
Metaplastik Ossifikasyon Gösteren Molluscum Contagiosum: Çok Nadir Bir Olgu
}

\author{
Hülya ETEM*
}

\section{$\ddot{\mathbf{O} z}$}

Molluscum Contagiosum (MC) sık görülen benign, viral bir hastalıktır. Çoğunlukla deriyi, nadiren mukozal membranları etkiler. Bu hastalık her yaş grubunda görülebilmekle birlikte, daha çok çocuklarda ve daha az olarak seksüel aktif erişkinlerde görülmektedir. MC hastalığında avuç içi ve ayak tabanı hariç vücudun her yerinde genellikle 3-5 mm çapında tek veya çok sayıda, ortasında göbeklenme gösteren papüllerle karakterize lezyonlar görülebilir. Histopatolojik incelemede Henderson-Paterson cisimcikleri olarak da bilinen intrasitoplazmik Molluscum cisimleri görülür. $\mathrm{Bu}$ olguda yirmi yedi yaşında kadın hastanın, yüzünde, sol malar bölge üzerinde $0.5 \mathrm{~cm}$ boyutunda sivilceye benzeyen lezyon gözlendi. Lezyon ekstirpe edildikten sonra histopatolojik incelemede metaplastik ossifikasyon gösteren MC tanısı konuldu. MC hastalığında metaplastik ossifikasyon çok nadir görüldüğü için bu olgu sunulmuştur.

Anahtar kelimeler: Molluskum Kontagiozum, metaplastik ossifikasyon, dermatoloji.

\section{Molluscum Contagiosum with Metaplastic Ossification: A Very Rare Case}

\begin{abstract}
Molluscum Contagiosum (MC) is a common, benign viral disease. It usually affects the skin and rarely mucosal membranes. Although this disease can be seen in all age groups, it is most commonly seen in children and sexually active adults. In MC disease, lesions characterized by a single or multiple, 3-5 mm diameter papules with a navel in the middle can be seen all over the body, except for the palm and soles. Histopathological examination shows intracytoplasmic Molluscum bodies also known as Henderson-Paterson bodies. In this case, an acne-like lesion

Olgu Sunumu (Case Report)

Geliş / Received: 05.01.2020 \& Kabul / Accepted: 15.07.2020

DOI: https://doi.org/10.38079/iqusabder.670423

${ }^{*}$ Dr. Öğr. Üyesi, Sağlık Bilimleri Üniversitesi, Gazi Yaşargil Eğitim ve Araştırma Hastanesi, Patoloji Bölümü, Diyarbakır, Türkiye, E-posta: hulya.etem@gmail.com

ORCID https://orcid.org/o000-0002-0469-2716
\end{abstract}


with a size of $0.5 \mathrm{~cm}$ on the left malar region was observed on the face of a 27-year-old female patient. After the lesion was extirpated, the diagnosis of $\mathrm{MC}$ showing metaplastic ossification was made on histopathological examination. This case is presented because metaplastic ossification is very rare in MC disease.

Keywords: Molluscum Contagiosum, metaplastic ossification, dermatology.

\section{Giriş}

Molluscum Contagiosum (MC), sık görülen, benign viral bir hastalıktır. Hastalığa Poxviridae familyasında bulunan molluscum contagiosum virus'u (MCV) neden olur. Virüs, cinsel aktivite de dahil olmak üzere doğrudan temasla veya havlu gibi kontamine nesnelerle yayılır. Sıklıkla deriyi, nadiren müköz membranları tutar. Bu hastalık her yaş grubunda görülebilmekle birlikte en çok çocuklarda görülür. Çocuklardan sonra seksüel aktif erişkinlerde, immun suprese bireylerde (örneğin AIDS lilerde) görülür ${ }^{1-2}$. MC avuç içi ve ayak tabanı hariç vücudun her yerinde görülebilir. En sık etkilenen bölgeler gövde, aksilla, antekübital fossa, popliteal fossa ve bacak kıvrımlarıdır. Ayrıca göz kapağında görüldüğünde konjuktivite neden olur³ ${ }^{3}$ Nadiren oral mukozada görülebilir ${ }^{4}$. Seksüel aktif erişkinlerde abdomen, genital bölge, uyluk iç kısımlarında görülür5 .

MC da lezyonlar tek veya multiple sayıda olup, çapı 3-5 mm arasında değişmektedir. Tipik olarak ortasında göbeklenme gösteren papüllerle karakterizedir ${ }^{6}$. Histopatolojik incelemede; hematoksilen-eozin boyamada tipik olarak Henderson-Patterson cisimcikleri olarak da bilinen eozinofilik-sitoplazmik inklüzyon cisimcikleri içerir ${ }^{7}$. MC da metaplastik ossifikasyon çok nadir görülen bir lezyondur .

\section{Olgu Sunumu}

Kendisinden aydınlatılmış onam alınan 27 yaşında kadın hastanın muayenesinde, yüzün sol malar bölgesine yerleşmiş sivilceye benzeyen tek bir lezyon tespit edildi. Ekstirpe edilen lezyon örneğinin makroskopik incelemesinde; $0.5 \times 0.5 \mathrm{~cm}$ boyutunda cilt/cilt altı dokusundan oluşmuş, ortasında kraterimsi yapısı olan lezyon izlendi. Histopatolojik incelemede epidermis hiperplazikti ve dermise doğru invajinasyon gözlendi. Epidermal hücrelerin birçoğunun sitoplazmasını dolduran büyük eozinofilik molluscum cisimcikleri (Handerson-Peterson cisimcikleri) izlendi. Malpighi tabakasında eozinofilik boyanan bu cisimciklerin yüzeye yaklaştıkça bazofilik özellik kazandığı dikkati çekti. 
Lezyonun ortasında, üst dermis yerleşimli metaplastik ossifikasyon görüldü (Resim 1-23).

Resim 1: Epidermiste hiperplazi ve dermise doğru invajinasyon gösteren enfekte hücrelerin sitoplazmasını dolduran büyük asidofilik molluscum cisimcikleri (mavi ok) ve metaplastik ossifikasyon (kırmızı ok) (Hematoksilen \& Eozin x10).

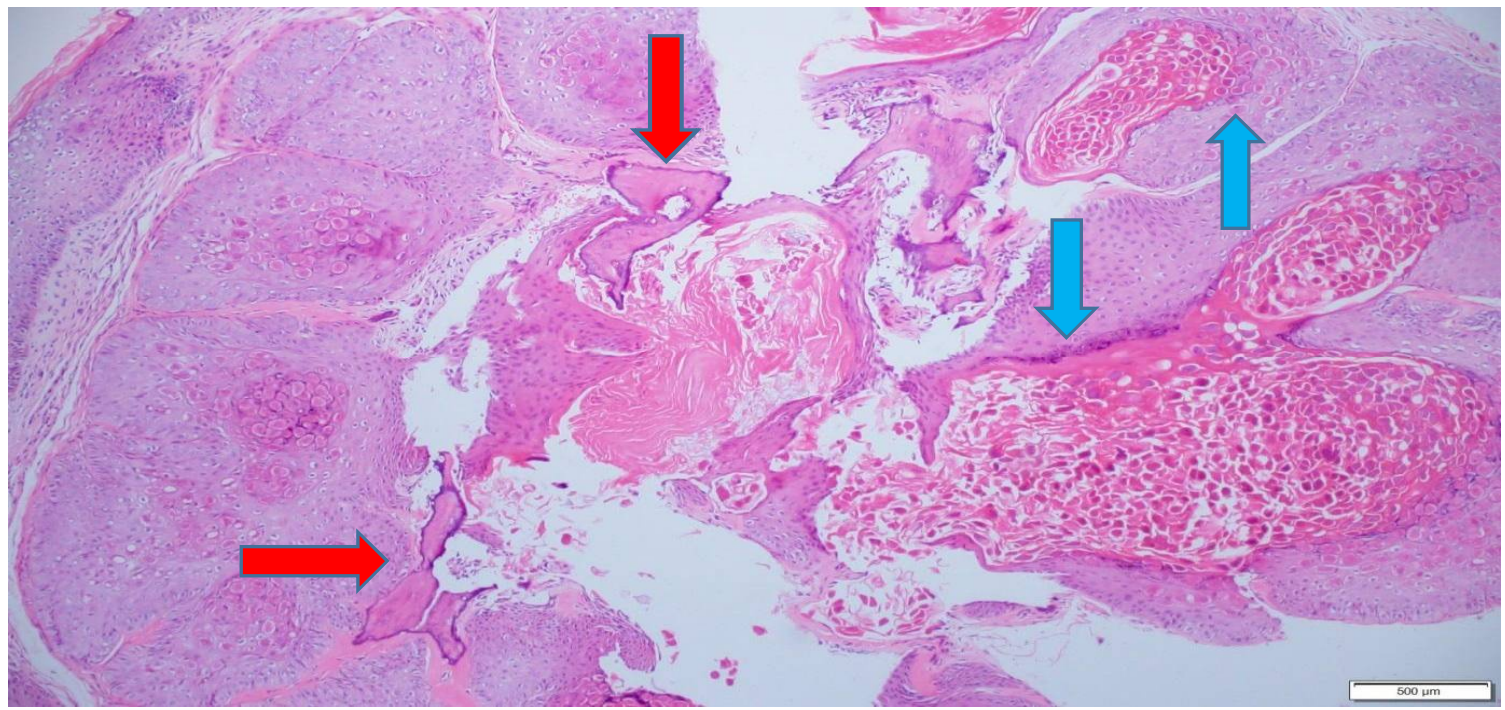

Resim 2: Lezyonun ortasında üst dermiste metaplastik ossifikasyon gösteren odak (kırmızı ok) molluscum cisimcikleri (mavi ok) (Hematoksilen \& Eozin x20)

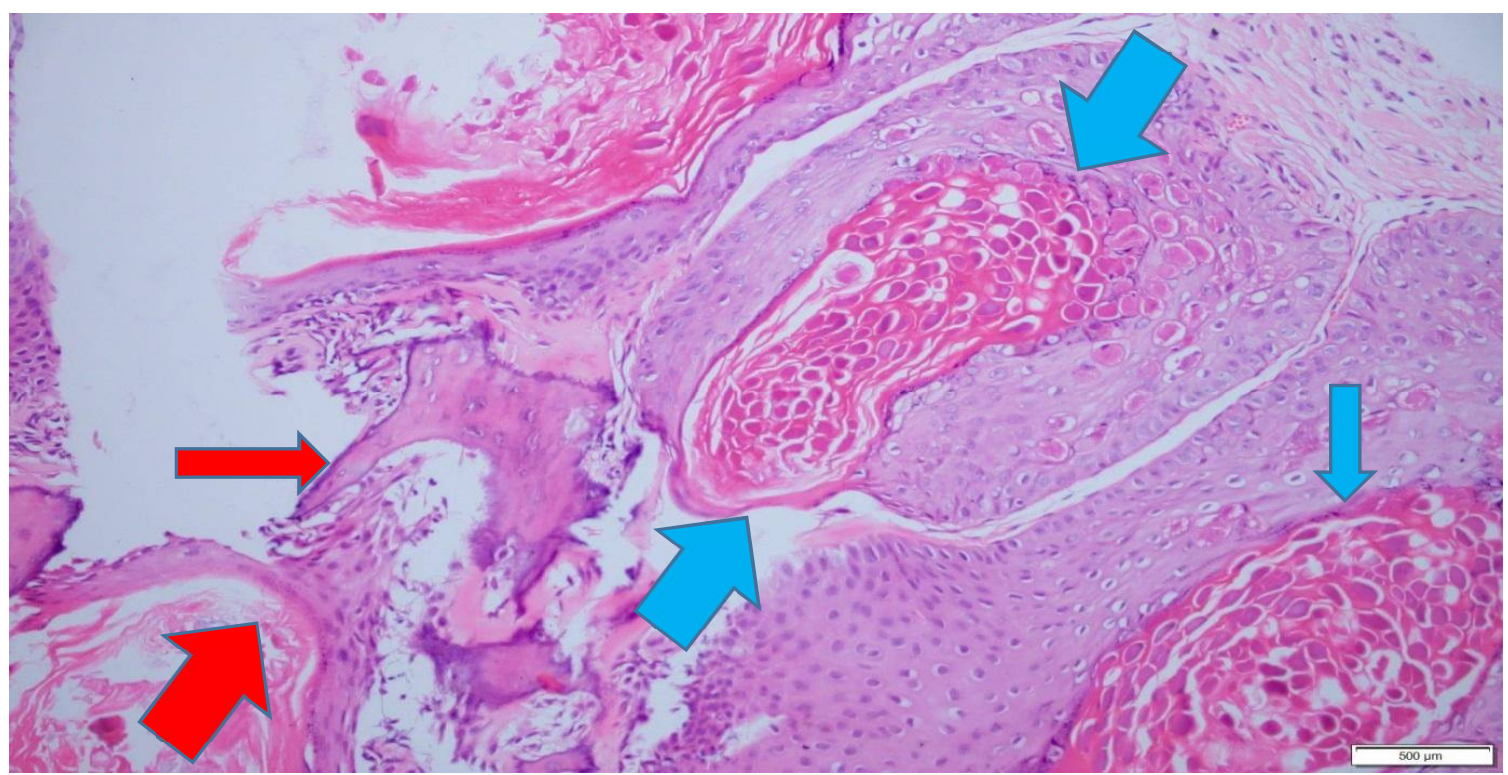


Resim 3: Ossifikasyon gösteren odağın (mavi ok) Molluscum cisimleriyle birlikte görüntüsü. Lezyonda dikkat çeken diğer bir özellik Molluscum cisimciklerinin eozinofilik boyandığı, yüzeye Malpighi tabakasına yaklaştıkça bazofilik boyandığı dikkat çekmektedir (kırmızı ok) (Hematoksilen \& Eozin x40).

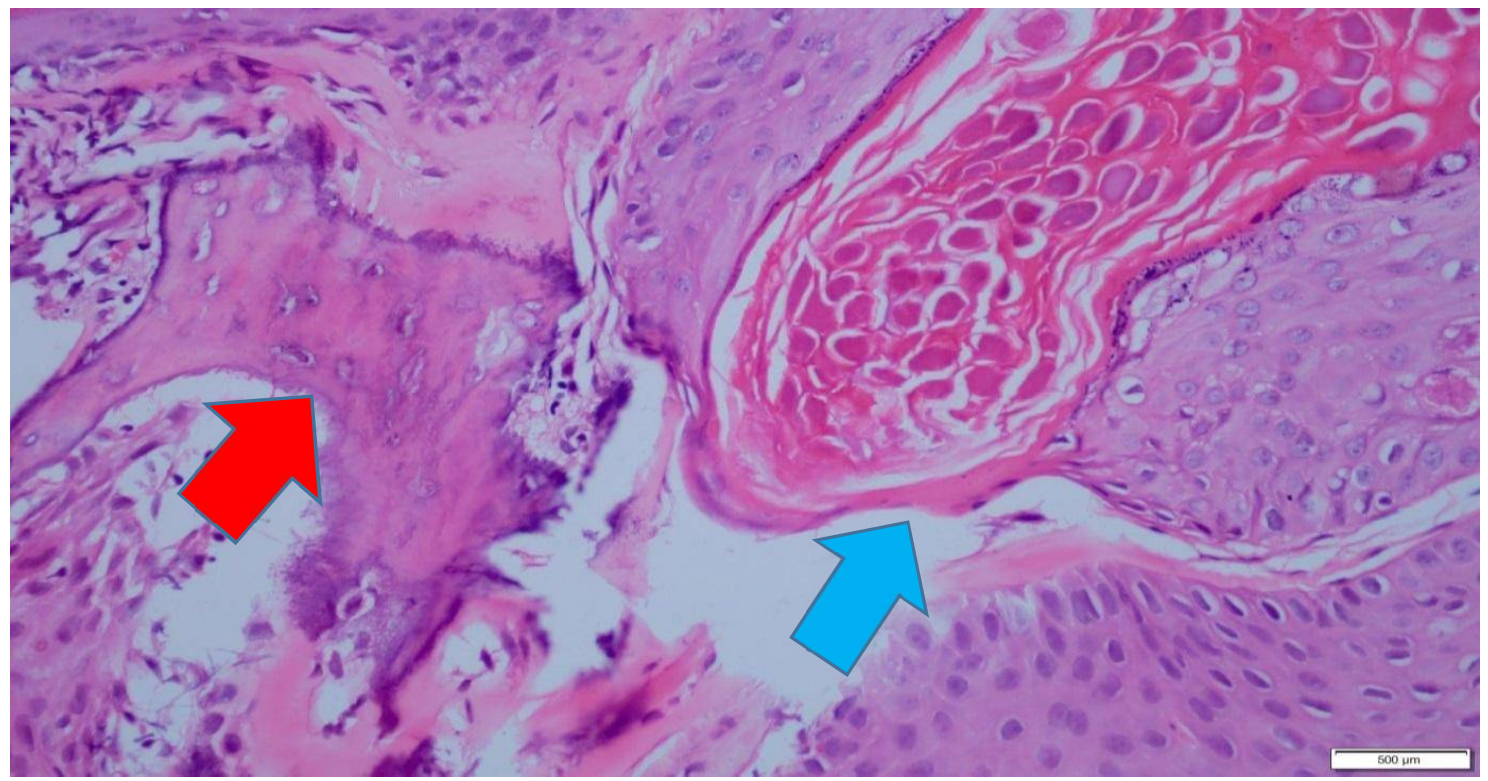

\section{Tartışma}

Molluscum contagiosum sık görülen, benign viral bir hastalıktır. MC da metaplastik ossifikasyon çok nadir görülmektedir ${ }^{8}$. Kutanöz kemik oluşumu primer veya sekonder olarak, inflamatuar veya neoplastik durumlarda oluşabilir. Primer olarak öncesinde bir deri lezyonu yokken oluşur. Sekonder olanda ise var olan bir lezyon üzerinde gelişiri, ${ }^{9,10}$. Primer lezyonlar Albright Herediter Osteodistrofisi, Progressif Osseöz Hiperplazi, Ailesel Multipl Ekzositozis, Osteoma Kutis de görülür ${ }^{10}$. Sekonder ossifikasyon ya da metaplastik ossifikasyon ise; inflamasyona, travmaya veya neoplastik oluşuma bağlı olarak gelişebilir. Neoplastik süreçe bağlı olarak gelişen metaplastik ossifikasyon nedenleri arasında; pilomatrikoma, akne vulgaris, epidermoid ve dermoid kist, melanositik nevüsler (Osteonevüs of Nanta), kondroid siringoma, trichoepitelyoma, piyojenik granülom, lipom, fibroksantom gibi benign lezyonlar ile bazal hücreli karsinom, malign melanoma gibi lezyonlar sayılabilir9-11. Malign tümör metastazlarında 
(meme, mesane, bronş karsinomu), yanık sonrasında, skar dokusunda, öncü kıkırdak dokusu gelişmeden oluşur ${ }^{10-12}$.

Kemik oluşumu kalsiyum-fosfor iyonlarının konsantrasyonuna, $\mathrm{pH}^{\prime}$ ya, oksijen basıncına ve osteojenik enzimlerin durumuna bağlıdır ${ }^{10}$. Kutanöz ossifikasyonlar kadınlarda daha fazla görülmektedir. Bunun sebebi osteoblastların yüzeylerinde östrojenler için reseptör bulunmasına bağlı olarak geliştiği şeklinde açıklanabilir 9,10.

\section{Sonuç}

Sonuç olarak; olgumuzda gözlenen metaplastik ossifikasyon var olan MC lezyonu içerisinde gelişmiştir. Metaplastik ossifikasyonda görülen kemik yapı kıkırdak doku içermeyen lameller kemik dokudan oluşmaktadır. Bu olgu bildirimi MC lezyonlarında metaplastik ossifikasyonun çok nadir görülmesi nedeniyle yapılmıştır.

\section{KAYNAKLAR}

1. Vanhooteghem O, Henrijean A, de la Brassinne M. Epidemiology, clinical picture and treatment of molluscum contagiosum: literature review. Ann Dermatol Venereol. 2008;135:326-32.

2. Dave S, Thappa DM, Karthikeyan K. Disseminated and disfiguring molluscum contagiosum in a patient with rheumatoid arthritis taking methotrexate. Clin Exp Dermatol. 2007;33:347.

3. Schornack MM, Siemsen DW, Bradley EA, et al. Ocular manifestations of molluscum contagiosum. Clin Exp Optom. 2006;89:390.

4. Fornatora ML, Reich RF, Gray RG, Freedman PD. Intraoral molluscum contagiosum: a report of case and a review of the literature. Oral Surg Oral Med Oral Pathol Oral Radiol Endod. 2001;92:318-320.

5. Nandhini G, Rajkumar K, Kanth KS, et al. Molluscum contagiosum in a 12-yearsold child-report of a case and review of literature. J Int Oral Health. 2015;7:6366.

6. Diven DG. An overview of poxviruses. J Am Acad Dermatol. 2001;44:1-14. 
7. Cotell SL, Roholt NS. Images in clinical medicine. Molluscum contagiosum in a patient with the acquired immunodeficiniency syndrome. $N$ Engl $J$ Med. 1998;338:888.

8. Naert F, Lachapella JM. Multipl lesions of Mollucum contagiosum with metaplastic ossification. Am. J. Dermapathol. 1989;11(3):238-241.

9. Al-Daraji W. Osteo-nevus of Nanta (osseous metaplasia in a benign intradermal melanocytic nevus): an uncommon phenomen. Dermatol Online $J$. 2007;13(4):16.

10. Conlin PA, Jimenez - Quintero LP, Rapini RP. Osteomas of the skin revisited: a clinicopathologic review of 74 cases. Am J Dermatopathol. 2002;24(6):479-83.

11. Kanitakis J, Claudy A. Mummified ossified melanocytic nevus. Eur J Dermatol. 2000;10(6):466-7.

12. Sasaki S, Mitsuhashi Y, Ito Y. Osteo-nevus of Nanta: a case report and review of the Japanese literature. J Dermatol. 1999;26(3):183-8. 